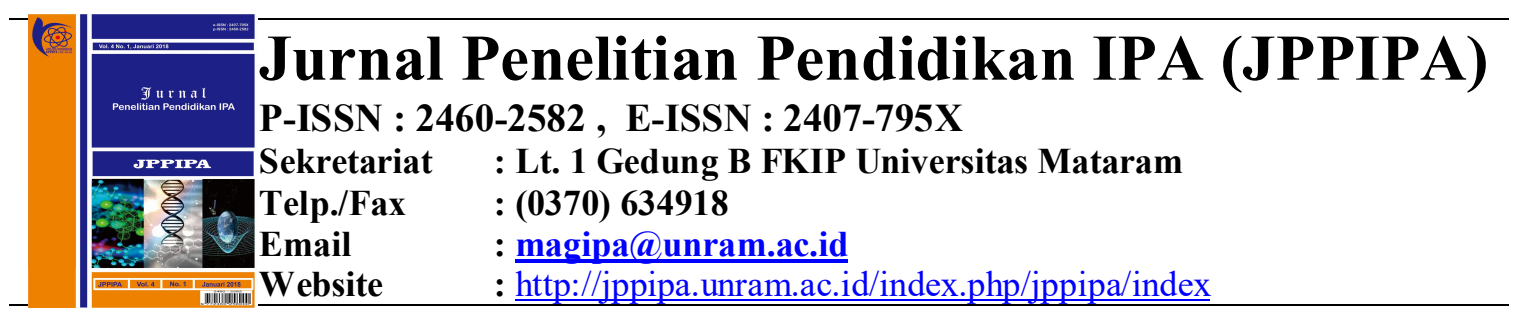

\title{
PENGEMBANGAN PERANGKAT PENILAIAN KINERJA (PERFORMANCE ASSESSMENT) BERBASIS KURIKULUM 2013 PADA PEMBELAJARAN KIMIA KELAS XI
}

\author{
Diartha $^{1}$ Wildan $^{2}$ Muntari $^{3}$ \\ Program Studi Magister Pendidikan IPA Program Pascasarjana Universitas Mataram ${ }^{123}$ \\ Email:
}

\begin{tabular}{|c|c|}
\hline Key Words & Abstract \\
\hline $\begin{array}{l}\text { Performance } \\
\text { assessment- } \\
\text { instrument, } \\
\text { Applicable, } \\
\text { Chemistry } \\
\text { learning }\end{array}$ & $\begin{array}{l}\text { This development research aimed to produce performance assessment } \\
\text { instrument on chemistry learning for XI grade, descibe for } \\
\text { characteristics, and validity tests. This research development used Dick } \\
\text { and Carey's model. The products consists of acid-base proved into } \\
\text { worksheet, evaluation of indicators, direction of usage, sheet of } \\
\text { observation, rubric of assessment, assessment of conversion, and value of } \\
\text { recapitulation. Validation's data of Aiken were } 0,60 \text { for unit one, unit two } \\
\text { for } 0,60 \text {, and } 0,66 \text { for unite three means valid. The data of experiment } \\
\text { were } 84 \% \text { for suitability, } 87 \% \text { for simplicity, and } 84 \% \text { for usefullness. } \\
\text { Application' data for suitability, simplicity, and usefullness were } 84 \% \text {, } \\
86 \% \text {, and } 84 \% \text { respectively. Upper validity correlation table within } 5 \% \text { of } \\
\text { significant level and reability inter-raters were } 0,76 \text { for unit one and } 0,75 \\
\text { for unit two. Application of assessment's instrument were positively } \\
\text { responded by students. Therefore, instrument of assessment in } 2013 \\
\text { curriculum-based stated applicable to be implemented in learning } \\
\text { process. }\end{array}$ \\
\hline Kata Kunci & Abstrak \\
\hline $\begin{array}{l}\text { Perangkat } \\
\text { penilaian } \\
\text { kinerja, } \\
\text { Layak, } \\
\text { Pembelajaran } \\
\text { kimia }\end{array}$ & $\begin{array}{l}\text { Penelitian ini bertujuan untuk menghasilkan perangkat penilaian kinerja } \\
\text { pada pembelajaran kimia kelas XI, mendeskripsikan karakteristiknya dan } \\
\text { menguji kelayannya. Penelitian pengembangan ini menggunakan model } \\
\text { Dick and Carey. Produk terdiri dari tiga unit perangkat penilaian } \\
\text { mengenai asam basa yang memuat tugas kinerja, kisi-kisi penilaian, } \\
\text { petunjuk penggunaan, lembar observasi, rubrik penilaian, pedoman } \\
\text { konversi penilaian, dan rekapitulasi nilai. Data validasi ahli dengan } \\
\text { koefisien Aiken sebesar } 0,60 \text { untuk unit satu dan dua } 0,66 \text { untuk unit tiga } \\
\text { yang berarti valid. Data uji coba yakni } 85 \% \text { mengenai kesesuaian, } 87 \% \\
\text { mengenai kemudahan, dan } 84 \% \text { mengenai kemanfaatan. Data uji } \\
\text { pemakaian mengenai kesesuaian, kemudahan, dan kemanfaatan berturut- } \\
\text { turut } 84 \% \text {, } 86 \% \text {, dan } 84 \% \text {. Validitas di atas koerlasi tabel dengan taraf } \\
\text { signifikan } 5 \% \text {, dan reliabilitas antar penilai yakni } 0,76 \text { unit satu dan tiga } \\
0,75 \text { untuk unit dua. Penerapan perangkat penilaian kinerja direspon } \\
\text { positif oleh peserta didik. Dengan demikian, perangkat penilaian kinerja } \\
\text { berbasis kurikulum } 2013 \text { dinyatakan layak dan dapat diterapkan pada } \\
\text { proses pembelajaran. }\end{array}$ \\
\hline
\end{tabular}




\section{PENDAHULUAN}

Asesmen merupakan komponen yang sangat penting dalam pelaksanaan kurikulum yang terintegrasi dalam proses pembelajaran. Asesmen merupakan sentral dalam pengajaran dan pembelajaran. Informasi yang diperoleh dari asesmen sangat dibutuhkan untuk membuat keputusan tentang kemampuan peserta didik, penempatan peserta didik pada tingkat yang sesuai, dan prestasinya (Yuen \& Kaur, 2010). Pendapat tersebut sejalan dengan Khadijeh \& Amir (2015) mengungkapkan bahwa asesmen merupakan respon paling penting bagi guru, karena kualitas pengajaran sangat erat kaitannya dengan kualitas penilaian yang diterapkan. Hal ini berarti perangkat penilaian hasil belajar hendaknya memiliki kualitas yang baik.

Pemerintah terus berupaya meningkatkan kualitas pendidikan, yaitu dengan menerapkan kurikulum 2013. Penerapan kurikulum 2013 dengan pendekatan saintifik menghendaki penilaian dilakukan sebelum, selama, dan sesudah proses pembelajaran. Selain itu, kurikulum 2013 menutut agar penilaian hasil belajar dilakukan dengan memberikan ruang kepada peserta didik untuk mengaktualisasikan kemampuan pengetahuan dan keterampilan yang dimiliki. Penilaian yang cocok dengan hal tersebut adalah penilaian otentik yang salah satunya yakni penilaian kinerja (performance assessment) (Depdikbud, 2013).

Pendidikan kimia berkaitan dengan cara mencari tahu dan memahami alam secara sistematis, sehingga kimia bukan hanya penguasaan konsep tetapi juga merupakan suatu proses penemuan. Pendidikan kimia menekankan pada pemberian pengalaman secara langsung. Untuk itu siswa perlu dibantu untuk mengembangkan sejumlah keterampilan proses agar mereka mampu memahami alam sekitarnya. Keterampilan ini meliputi mengamati, menanya, mencoba, menalar, dan mengkomunikasikan yang sangat sesuai apabila diterapkan dalam praktikum. Kegiatan ini digunakan untuk lebih memahami teori dan melatih keterampilan dasar.

Keterampilan peserta didik tidak seharusnya diukur berdasarkan hasil tes tertulis seperti terlihat pada hasil survey. Setiap aspek hasil belajar harus diukur menggunakan instrumen penilaian yang sesuai. Untuk aspek keterampilan, instrumen yang digunakan adalah. Instrumen yang digunakan harus memiliki kualitas baik yakni valid dan reliabel. Namun pada kenyataanya, yang terjadi di sekolah seperti yang diperoleh pada hasil survey, guru masih menggunakan tes tulis kalaupun menggunakan tes non tulis tetapi tidak sesuai dengan standar umum.

Marmara (2008) mengungkapkan, performance assessment merupakan penilaian dimana siswa melakukan suatu kegiatan atau prosedur produk untuk menunjukkan pengetahuan dan keterampilan yang dimiliki. Penerapan performance assessment memungkinkan siswa untuk mengembangkan keterampilan metakognisi. Menurut Oberg (2012), dengan menggunakan performance assessment pendidik mendapatkan gambaran secara lengkap tentang apa yang peserta didik ketahui dan lakukan. Dengan data tersebut, pendidik dapat meningkatkan kualitas pembelajaran sehingga lebih menarik dan melibatkan peserta didik dalam proses penilaian.

Berdasarkan uraian di atas, maka tujuan penelitian ini mengembangkan perangkat performance assessmentberbasis kurikulum 2013 serta mengetahui karakteristik dan kelayakan sehingga dapat digunakan dalam pembelajaran kimia di SMA/MA.

\section{METODOLOGI}

Metode penelitian ini adalah menggunakan metode research and development atau penelitian pengembangan. Pada penelitian pengembangan ini akan dikembangkan perangkat performance assessmentberbasis 
kurikulum 2013 pada pembelajaran kimia. Penelitian dan pengembangan perangkat performance assessmentpada penelitian ini menggunakan model Dick and Carey, yakni (1) Mengidentifikasi tujuan pengembangan, (2) Melakukan analisis pembelajaran, (3) Menganalisis karakteristik siswa dan konteks pembelajaran, (4) Merumuskan tujuan pencapaian kompetensi, Mengembangkan instrumen penilaian, (6) Mengembangkan strategi pembelajaran, (7) Mengembangkan dan memilih bahan ajar, (8) Mendesain dan melakukan evaluasi formatif, (9) Revisi produk, dan (10) Merancang dan mengembangkan evaluasi sumatif.

Subyek dalam penelitian pengembangan ini adalah subyek uji coba dan uji pemakaian yakni tujuh guru kimia dan 67 peserta didik pada lima SMAN di Lombok Utara. Lokasi penelitian terdiri dari tahap pengembangan dilaksanakan di Program Magister IPA dan tahap uji pemakaian dilaksanakan di dua SMAN tersebut di atas. Waktu pelaksanaan Okteber 2014 hingga November 2015.

Pengumpulan data, pada tahap validasi data diperoleh dari pengisian angket uji kesesuain substansi, konstruksi, dan bahasa oleh tiga dosen ahli, lembar pengisian lembar observasi kinerja peserta didik, angket respon guru serta angket respon peserta didik. Teknik analsis data dengan formula Aiken untuk data validasi ahli, formula Product Moment untuk menentukan validitas butir instrumen produk, formula Alpha Cronbach untuk menentukan reliabilitas internal, dan formula Kappa Cohen untuk menentukan reliabilitas antar penilai. Dan, teknik analisis angket guru dilakukan dengan cara(1) memberi skor setiap jawaban item dengan menggunakan skala Likert, seperti pada Tabel 1.

Tabel 1. Skala Likert

\begin{tabular}{clc}
\hline No & Jawaban aitem pertanyaan & Skor \\
\hline 1. & Sangat tidak sesuai & 1 \\
2. & Tidak sesuai & 2 \\
3. & Sesuai/jelas & 3 \\
4. & Sangat sesuai & 4 \\
\hline
\end{tabular}

Selanjutnya, (2) mengolah skor, (3) menghitung persentase setiap aspek penilaian, dan (4) melakukan interpretasi terhadap persentase penilaian guru dengan menggunakan kriteria pada tabel 2 .

Tabel 2. Katagori Rentang Skor

\begin{tabular}{cc}
\hline Rentang \% & Katagori \\
\hline $81-100$ & Baik sekali \\
$61-80$ & Baik \\
$41-60$ & Cukup \\
$21-40$ & Kurang \\
$<21$ & Kurang sekali \\
\hline
\end{tabular}

Untuk angket peserta didik dianalisis dengan cara: (1) memberi skor pada jawaban setiap item dengan menggunakan skala Likert, seperti tabel 3.

Tabel 3. Skala Likert

\begin{tabular}{ccccc}
\hline \multirow{2}{*}{ Pernyataan } & \multicolumn{4}{c}{ Skor } \\
\cline { 2 - 5 } & SS & S & TS & STS \\
\hline Positif & 4 & 3 & 2 & 1 \\
\hline (Ridwan, 2011) & & & &
\end{tabular}

(Ridwan, 2011)

Selanjutnya, (2) mengolah skor, (3) menghitung persentase dengan persamaan:

$$
=\frac{\sum \text { skor yang diperoleh }}{\sum \text { skor maksimal }} \times 100 \%
$$

(4) melakukan interpretasi menggunakan kriteria paada tabel 4.

Tabel 4. Katagori Rentang Skor

\begin{tabular}{cc}
\hline Rentang $\%$ & Katagori \\
\hline $81-100$ & Sangat setuju \\
$61-80$ & Setuju \\
$41-60$ & Cukup setuju \\
$21-40$ & Tidak setuju \\
$<21$ & Sangat tidak setuju \\
\hline
\end{tabular}

\section{HASIL DAN PEMBAHASAN}

Hasil utama dari penelitian pengembangan ini adalah perangkat penilaian kinerja, dimana perangkat tersebut digunakan untuk menilai kinerja psikomotor peserta didik pada pembelajaran kimia berbasis kurikulum 2013 pada kelas XI. Hasil dari setiap tahapan prosedur pengembangan yang dilakukan sebagai berikut:

1. Mengidentifikasi Tujuan

Berdasarkan hasil survey di SMAN 1 Bayan dan SMAN 1 Gangga, diketahui 
permasalahan terkait perangkat penilaian ketrampilan peserta didik yaitu tidak ada perangkat penilaian yang digunakan untuk menilai ketrampilan peserta didik, kalupun ada tetapi masih bersifat umum. Bentuk penilaian menggunakan skala, tetapi tidak menggunakan kriteria penilaian. Akibatnya, guru menilai ketrampilan peserta didik secara subyektif. Oleh karena itu, kebutuhan akan perangkat performance assessmentsangat diperlukan pada pembelajaran kimia. Selanjutnya dilakukan kajian pustaka dari buku dan jurnal berkenaan dengan perangkat penilaian kinerja. Berdasarkan kajian pustaka yang dilakukan peneliti, sejauh ini belum ada pengembangan perangkat performance assessmentberbasis kurikulum 2013 pada materi asam basa.

2. Melakukan Analisis Instruksional Tahapan ini, peneliti menentukan pengetahuan, keterampilan, dan sikap, yang dikenal sebagai kompetensi prasyarat yang diperlukan siswa dalam bentuk peta konsep. Peta konsep asam basa meliputi pengidentifikasian, penentuan $\mathrm{pH}$ atau derajat keasaman dan juga sifat-sifat senyawa asam basa maupun garam.

3. Menganalisis Karakteristik Peserta Didik dan Konteks Pembelajaran

a. Analisis Latar Belakang Siswa

Materi asam basa telah diperoleh diperoleh peserta didik pada saat di SMP dan materi prasyarat yang harus dipelajari adalah larutan elektrolit dan nonelektrolit (Depdikbud, 2013).

b. Analisis Perkembangan Kognitif Peserta Didik

Usia peserta didik rata-rata $15-16$ tahun. Menurut Badrul (2013) , pada usia tersebut anak belum memasuki operasi formal. Oleh karena itu, guna menunjang pembelajaran kimia yang bersifat abstrak serta mengaitkannya dalam kehidupan nyata diperlukan metode praktikum. Proses pembelajaran anak perlu dilakukan penilaian nyata yaitu penilaian kineja.

\section{c. Analisis Tugas}

Berdasarkan tahapan di atas, maka dilakukan analisis tugas yaitu dalam bentuk tugas kinerja, yakni mempersiapkan alat dan bahan, menggunakan alat dan bahan, dan mengkomunikasikan hasil. Berdasarkan analisis KD 4.10 dan KD 4.11, maka telah terbentuk tugas kinerja I, II, dan III.

4. Merumuskan Tujuan Kompetensi

Tahapan ini dilakukan untuk merumuskan hasil analisis tugas menjadi tujuan pencapaian hasil belajar. Tujuan pembelajaran pada ranah psikomotor yaitu peserta didik dapat: menyiapkan alat dan bahan, (2) menggunakan alat dan bahan, (3) mengamati hasil, (4) mencatat hasil, (5) menyimpulkan, dan mengkomunikasikan hasil.

5. Mengembangkan Perangkat Penilaian

Peneliti mengembangkan perangkat performance assessmentmengikuti anjuran Moskal dalam Wren (2009), tiga tahap utama proses pengembangan performance assessmentyakni (a) menetapkan pengetahuan dan keterampilan yang akan dinilai, (b) mendesain tugas-tugas performance, (c) menetapkan sistem scoring. Penetapan performance yang akan dievaluasi mengacu kompetensi aspek psikomotor. Tugas-tugas performance didesain tujuan pencapaian kompetensi. Selanjutnya, sistem scoring menggunakan rubrik penilaian yang berskala 1-4. Skor empat diberikan ketika peserta didik dapat menyelesaikan tugas kinerja dengan sempurna sesuai dengan kriteria. Kemudian skor satu diberikan ketika peserta didik menyelesaikan tugas kinerja tidak satupun memenuhi kriteria, atau ketika peserta didik tidak mengerjakan tugas kinerja.

6. Mengembangkan Strategi Pembelajaran

Kurikulum 2013 menekankan pada penerapan pendekatan saintifik dalam pembelajaran dimana siswa dapat 
mengeksplor kemampuannya secara mandiri melalui proses mengamati, menanya, mencoba, menalar, dan mengkomunikasikan dengan sistem penilaian otentik (penilaian kinerja). Model pembelajaran yang mengapresiasi lima keterampilan dan sistem penilaian tersebut adalah model discovery learning (Kemendikud, 2013).

7. Mengembangkan dan Memilih Bahan Ajar

Mengembangkan dan memilih bahan ajar disesuaikan dengan tipe pembelajaran yang diterapkan saat penelitian berlansung yakni discovery learning. Selanjutnya, peneliti mengembangkan RPP berdasarkan hasil yang diperoleh pada tahap merumuskan tujuan pencapaian kompetensi dan disesuaikan dengan discovery learning. Mendesain dan Melakukan Evaluasi Formatif

Peneliti menggunakan tipe evaluasi expert(s) review (validasi) dan field evaluation . Expert(s) review diperoleh melalui tahap penilaian perangkat penilaian melalui proses validasi oleh dosen ahli. Para ahli meninjau draft perangkat penilaian yang dikembangkan untuk menentukan kekuatan dan kelemahannya kemudian memberikan penilaiannya. Hasil penilaian terhadap tiga perangkat performance assessment hasil pengembangan disajikan dalam tabel 5.

Tabel 5. Rekapitulasi Validasi Draft Perangkat Penilaian

\begin{tabular}{cccc}
\hline No & $\begin{array}{c}\text { Perangkat } \\
\text { penilaian }\end{array}$ & Rerata & Keterangan \\
\hline 1. & I & 0,60 & Revisi \\
2. & II & 0,60 & Revisi \\
3. & III & 0,66 & Revisi \\
\hline
\end{tabular}

Field evaluation dilakukan dengan meminta penilaian dari tiga orang kimia pada tahap uji coba produk yang dilakukan di SMAN 1 Kayangan, SMAN 1

Pamenang, dan SMAN 1 Tanjung. Selanjutnya, field evaluation pada uji pemakaian dilakukan di SMAN 1 Bayan dan SMAN 1 Gangga. Hasil uji coba dan uji pemakaian produk pengembangan disajikan pada tabel 6 .

Tabel 6. Data Uji Produk

\begin{tabular}{lccl}
\hline \multirow{2}{*}{ Jenis Uji } & \multicolumn{2}{c}{$\%$ rata-rata } & \\
\cline { 2 - 3 } & Uji & Uji & Katagori \\
& Coba & Pakai & \\
\hline Kesesuaian & 85 & 84 & Sangat Baik \\
Kemudahan & 87 & 86 & Sangat Baik \\
Kemanfaatan & 84 & 84 & Sangat Baik \\
\hline
\end{tabular}

Selanjutnya, hasil angket respon peserta didik terhadap penerapan performance assessmentpada pembelajaran kimia mengenai asam basa menunjukkan hasil yang positif dimana seluruh siswa sangat setuju penerapan perangkat tersebut.

8. Revisi terhadap Produk Pengembangan

Berdasarkan masukan dan saran dari dosen dosen ahli, draft perangkat performance assessmentyang dikembangkan kemudian dilakukan revisi sesuai dengan kekurangannya.

9. Evaluasi Sumatif

Evaluasi sumatif merupakan jenis evaluasi yang dilakukan setelah evaluasi formatif yang melibatkan penilai independen. Oleh karena itu, pada penelitian ini peneliti tidak melaksanakan tahapan ini.

\section{Implementasi Produk}

Hasil nilai kinerja psikomotor diperoleh setelah dilakukan penilaian dengan didasarkan pada ketiga aspek tersebut. Data nilai hasil belajar kinerja psikomotor siswa secara keseluruhan disajikan pada tabel 7.

Tabel 7. Nilai Peserta Didik SMAN 1

Bayan

\begin{tabular}{lccc}
\hline \multirow{2}{*}{ Parameter } & \multicolumn{3}{c}{ Nilai Statistik } \\
\cline { 2 - 4 } & $\begin{array}{c}\text { Identifikasi } \\
\text { Asam Basa }\end{array}$ & $\begin{array}{c}\text { Kekuatan } \\
\text { Asam } \\
\text { Basa }\end{array}$ & $\begin{array}{c}\text { Titrasi } \\
\text { Asam } \\
\text { Basa }\end{array}$ \\
\hline Subjek & 23 & 23 & 23 \\
Penelitian & & & \\
Skor Ideal & 4 & 4 & 4 \\
Rata-rata & 3,27 & 3,25 & 3,28 \\
Terendah & 2,69 & 2,73 & 2,69 \\
Tertinggi & 3,75 & 3,73 & 3,66 \\
Kriteria & Sangat & Baik & Baik \\
Klasikal & Baik & & \\
\hline
\end{tabular}


Tabel 8 Nilai Peserta Didik SMAN

1 Gangga

\begin{tabular}{|c|c|c|c|}
\hline \multirow{3}{*}{ Parameter } & \multicolumn{3}{|c|}{ Nilai Statistik } \\
\hline & \multirow{2}{*}{$\begin{array}{l}\text { Identifikasi } \\
\text { Asam Basa }\end{array}$} & \multirow{2}{*}{$\begin{array}{c}\text { Kekuatan } \\
\text { Asam Basa }\end{array}$} & \multirow{2}{*}{$\begin{array}{l}\text { Titrasi } \\
\text { Asam } \\
\text { Basa }\end{array}$} \\
\hline & & & \\
\hline Subjek & 29 & 29 & 29 \\
\hline \multicolumn{4}{|l|}{ Penelitian } \\
\hline Skor Ideal & 4 & 4 & 4 \\
\hline Rata-rata & 3,31 & 3,24 & 3,22 \\
\hline Terer & 2,69 & 2,67 & 2,69 \\
\hline Tertinggi & 3,84 & 3,77 & 3,75 \\
\hline Kriteria & Sangat & Baik & Baik \\
\hline Klasikal & Baik & & \\
\hline \multicolumn{4}{|c|}{$\begin{array}{l}\text { Selanjutnya, dilakukan analisis } \\
\text { terhadap lembar observasi kinerja peserta } \\
\text { didik yang bertujuan untuk mengetahui } \\
\text { validitas butir instrumen, reliabilitas } \\
\text { internal instrumen, dan reliabilitas antar } \\
\text { penilai dari produk pengembangan. } \\
\text { Berdasarkan hasil analisis, koefisien rata- } \\
\text { rata validitas, reliabilitas internal, dan } \\
\text { reliabilitas antar penilai tersaji pada tabel } 9 .\end{array}$} \\
\hline \multicolumn{4}{|c|}{ Tabel 9 Validitas, Reliabilitas Produk } \\
\hline \multirow[b]{2}{*}{ Produk } & & Parameter & \\
\hline & Validitas & $\begin{array}{l}\text { Reliabilitas } \\
\text { Internal }\end{array}$ & $\begin{array}{l}\text { eliabilitas } \\
\text { Antar } \\
\text { Penilai }\end{array}$ \\
\hline Unit I & 0,64 & 0,90 & 0,76 \\
\hline Unit II & 0,69 & 0,88 & 0,75 \\
\hline $\begin{array}{l}\text { Unit } \\
\text { III }\end{array}$ & 0,65 & 0,85 & 0,76 \\
\hline
\end{tabular}

Kajian tentang produk pengembangan yang telah direvisi, meliputi karakteristik produk hasil pengembangan dan kelayakan serta deskripsi kesesuaian, kemudahan, dan kemanfaatan penggunaan produk hasil pengembangan menurut pendapat guru.

\section{Karakteristik Produk}

Tujuan penelitian dan pengembangan pada penelitian ini adalah menghasilkan perangkat performance assessment berbasis kurikulum 2013 pada pembelajaran kimia. Perangkat performance assessment ini merupakan perangkat penilaian untuk menilai aspek psikomotor peserta didik kelas XI mengenai sub materi identifikasi asam basa, kekuatan asam basa, dan titrasi asam basa sehingga terbetuk tiga unit perangkat penilaian. Perangkat performance assessment dikembangkan untuk membantu guru kimia dalam melaksanakan penilaian aspek psikomotor di kelas.

Perangkat performance assessment yang dikembangkan sudah melalui uji validitas isi oleh tiga orang ahli. Pengujian validitas isi dilakukan berdasarkan analisis rasional oleh ahli. Hal ini sesuai pendapat Azwar (2009) yang menyatakan bahwa validitas isi merupakan validitas yang diestimasi melalui pengujian terhadap isi tes dengan rasional ahli. Koefisien rata-rata menunjukkan nilai sebesar 0,60 untuk unit satu dan unit dua, serta 0,66 untuk unit tiga sehingga dapat diinterpretasikan bahwa indikator dan deskripsi indikator yang dikembangkan dapat digunakan dan telah sesuai dengan kemampuan yang dapat ditampilkan peserta didik pada performance assessment pembelajaran kimia.

Selain itu pula, telah dilakukan revisi baik mengenai aspek konstruksi, aspek subsatansi, dan aspek kebahasaan. Dengan demikian, perangkat performance assessment hasil pengembangan sudah layak dari ketiga aspek. Hal ini dipertegas dengan Permendikbud Nomor 66 Tahun 2013 tentang Standar Penilaian Pendidikan bahwa instrumen penilaian harus memenuhi persyaratan substansi yang mempresentasikan kompetensi yang dinilai, penggunaan bahasa yang baku serta komunikatif sesuai dengan tingkat perkembangan peserta didik, dan konstruksi yang memenuhi persyaratan teknis sesuai dengan bentuk instrumen yang digunakan.

Perangkat performance assessment yang dihasilkan dalam penelitian ini memuat tugas kinerja, kisi-ksi instrumen, petunjuk penggunaan, lembar observasi peserta didik, rubrik penilaian, pedoman konversi penilaian sesuai kurikulum 2013, dan rekapitulasi nilai akhir. Tugas kinerja memuat aspek-aspek keterampilan yang akan diobservasi yang diadopsi dari modul hasil penelitian dan pengembangan Apriadi tahun 2015. Kisi-kisi instrumen memuat 
indikator-indikator aspek psikomotor sesuai standar isi, petunjuk penggunaan merupakan keteranagan cara penggunaan instrumen. Selanjutnya, lembar observasi memuat kumpulan aspek-aspek pengamatan mengenai kinerja peserta didik yang berhubungan dengan konten pembelajaran mengenai identifikasi asam basa, kekuatan asam basa, dan titrasi asam basa. Skor yang diperoleh pada setiap aspek pengamatan kemudian direkapitulasi menjadi nilai akhir yang menyatakan kualitas kinerja peserta didik dalam pembelajaran.

Perangkat performance assessment hasil pengembangan ini memiliki keunggulan yaitu bentuk instrumen dapat diandalkan oleh guru untuk mengukur kinerja peserta didik secara objektif sesuai tuntutan kurikulum 2013, guru tidak mengalami kesulitan dalam melakukan penilaian karena dilengkapi skenario pembelajaran. Selain itu, perangkat penilaian ini dilengkapi kisi-kisi sehingga guru dapat mengarahkan peserta didik untuk menunjukkan kinerjanya sesuai keterampilan pada kisi-kisi tersebut. Perangkat penilaian ini dibuat secara detail sehingga guru dapat menilai kinerja peserta didik secara lebih akurat. Keunggulan perangkat penilaian ini sejalan dengan Yuen \& Kaur (2010) mengungkapkan pembelajaran menjadi lebih efektif karena penilaian terintegrasi dalam proses pembelajaran dan memberikan umpan balik. Omidi, Sridhar, dan Azizmalayeri (2012) berpendapat penggunaan performance assessment di dalam kelas membuat pembelajaran menjadi lebih aktif dan peserta didik lebih termotivasi terhadap materi ajar. Oberg (2012), menggunakan performance assessment pendidik mendapatkan gambaran secara lengkap tentang apa yang peserta didik ketahui dan lakukan. Dengan data tersebut, pendidik dapat meningkatkan kualitas pembelajaran sehingga lebih menarik dan melibatkan peserta didik dalam proses penilaian.

\section{Kesesuaian, Kemudahan, dan Kemanfaatan Produk}

Analisis angket respon guru menunjukkan persentase yang diperoleh mengenai kesesuaian adalah $88 \%$ yang berarti sangat tinggi. Berdasarkan hasil tersebut, peneliti menyimpulkan bahwa perangkat performance assessmen thasil pengembangan telah sesuai untuk digunakan. Hal tersebut didasarkan bahwa perangkat performance assessment hasil pengembangan sudah sesuai dengan tuntutan kompetensi inti dan kompetensi dasar yang menekankan aspek keterampilan dengan instrumen yang sesuai. Pendapat tersebut sejalan dengan Wren (2009), bahwa perangkat performance assessment harus dapat digunakan oleh guru sebagai alat evaluasi pada aspek keterampilan. Prinsip performance assessment adalah lebih menekankan pada keterampilan proses dan kemampuan menyelesaikan tugas-tugas yang yang diberikan.

Hasil analisis angket respon guru terhadap perangkat performance assessment pengembangan mengenai kemudahan diperoleh persentase $84 \%$ yang berarti sangat tinggi. Peneliti menyimpulkan bahwa instrumen yang dikembangkan mudah untuk digunakan namun terlalu banyak aspek yang diamati. Walaupun demikian, pengguna tidak memberikan saran perbaikan karena produk sudah baik dan mudah digunakan. Hal itu dapat ditunjukkan pada lembar observasi hampir semua aspek kinerja dapat diukur.

Berdasarkan uji pemakaian produk, persentase yang diperoleh adalah $86 \%$ yang berarti sangat tinggi. Kesimpulan peneliti diperoleh dari analisis angket respon guru mengenai kemanfaatan adalah instrumen sangat bermanfaat untuk digunakan karena instrumen hasil pengembangan telah memenuhi syarat kemanfaatan penggunaan instrumen. Pendapat tersebut sejalan dengan yang dikemukakan Hutabarat (2004), bahwa perangkat performance assessment lebih bermanfaat jika dapat digunakan untuk menilai kemampuan peserta didik dalam menyajikan lisan, 
pemecahan masalah dalam kelompok, partisipasi peserta didik dalam pembelajaran, dan kemampuan peserta didik dalam menggunakan peralatan dan bahan di laboratorium serta kemampuan peserta didik dalam mengoperasikan alat. Isyanti (2004) mengemukakan bahwa performance assessment bermanfaat untuk mengungkapkan potensi siswa dalam memecahkan masalah, penalaran, dan komunikasi dalam bentuk tulisan maupun lisan.

Hasil analisis angket respon peserta didik terhadap penerapan perangkat performance assessment pada pembelajaran kimia direspon sangat positif. Berdasarkan hasil tersebut, peneliti berkesimpulan bahwa penerapan performance assessment menjadikan siswa lebih aktif dalam pembelajaran dan bersemangat untuk mendapatkan nilai terbaik. Pendapat yang sama dikemukakan Wren (2009), Oberg (2012), bahwa penerapan perangkat performance assessment menjadikan siswa untuk meningkatkan kemampuan berpikir tingkat tinggi dan semangat untuk brepretasi.

Berdasarkan data hasil belajar aspek psikomotor peserta didik pada penerapan performance assessment di kedua SMAN di Lombok Utara, peneliti menyimpulkan bahwa pembelajaran dengan menerapkan perangkat performance assessment dapat meningkatkan hasil belajar peserta didik. Hal ini terlihat pada hasil belajar psikomotor peserta didik sebesar 57\% dengan katagori sangat baik.

Dengan demikian perangkat performance assessment hasil pengembangan telah memiliki kesesuaian dengan tuntutan kompetensi inti dan kompetensi dasar dengan lebih menekankan pada aspek psikomotor. Selain itu, produk hasil pengembangan dengan mudah dapat digunakan hanya saja aspek yang diukur cukup banyak sehingga dengan dua observer diperlukan konsntrasi yang tinggi. Instrumen hasil pengembangan bermanfaat dalam proses pembelajaran karena guru terbantukan dalam proses evaluasi khusus pada aspek psikomotor yang selama ini tidak pernah dilakukan sesuai tuntutan kurikulum. Disamping itu juga, perangkat performance assessment dapat memotivasi siswa dalam proses pembelajaran dan meningkatkan prestasi.

\section{Validitas dan Reliabilitas Produk}

Uji validitas ahli terhadap perangkat performance assessmentmenunjukkan hasil dengan dengan koefisien sebesar 0,60 untuk satu dan dua, serta 0,66 untuk unit tiga. Hal ini berarti bahwa perangkat performance assessment hasil pengembangan layak untuk digunakan. Hal ini didasarkan pada alasan bahwa perangkat penilaian hasil pengembangan telah disusun berdasarkan KI dan KD yang menekankan aspek keterampilan dan telah memenuhi syarat kesesuaian instrumen. Pendapat tersebut sejalan dengan pendapat yang dikemukakan Wren (2009), bahwa perangkat performance assessment harus dapat digunakan oleh guru sebagai alat untuk menilai hasil belajar aspek keterampilan. Prinsip dari perangkat performance assessment adalah lebih menekankan pada keterampilan proses dan kecakapan dalam menyelesaikan tugas yang diberikan.

Validitas empirik perangkat performance assessment hasil pengembangan memberikan koefisien korelasi pada taraf signifikan 5\% sebesar 0,64 untuk perangkat penilaian unit satu, dan 0,69 untuk perangkat performance assessment unit dua, serta 0,65 untuk perangkat performance assessment unit tiga yang berarti ketiga perangkat penilaian hasil pengembangan adalah valid. Peneliti menyimpulkan bahwa kreteria penilaian telah direview ahli dan penyusunan kriteria penilaian tidak menimbulkan persepsi yang berbeda diantara pengguna. Alasan ini sejalan dengan Popham (2011) mengemukakan bahwa kriteria yang paling penting yang dapat digunakan untuk menilai tugas-tugas berkaitan dengan kinerja peserta didik adalah faktor kesamaan. Dengan demikian, penetapan kriteria sangat diperlukan guna 
mendapatkan validitas perangkat penilaian yang dikembangkan.

Koefisien reliabilitas internal perangkat performance assessment termasuk dalam katagori sangat tinggi, artinya minimnya perbedaan keputusan penskoran terhadap kinerja yang sama. Hal ini berarti subyektivitas dalam penilaian dapat terhindarkan. Selain itu, reliabilitas antar penilai pada uji coba skala terbatas menunjukkan hasil 0,76 termasuk dalam katagori baik $(>70)$. Hal ini terjadi karena pengamat memberikan skor sesuai dengan kinerja yang ditampilkan. Hal ini dapat terjadi karena pengamat adalah guru kimia yang telah mengikuti pelatihan teknis kurikulum 2013 sehingga memiliki pemahaman yang sama. Pendapat ini sejalan dengan Popham (2011), bahwa sumber kesalahan penskoran dalam performance assessment karena adanya faktor personal-bias errors.

\section{KESIMPULAN}

Simpulan penelitian pengembangan ini adalah (1) perangkat performance assessment pembelajaran kimia berbasis kurikulum 2013 untuk kelas XI yang dihasilkan melalui suatu proses pengembangan memiliki karakteristik berupa seperangkat penilaian yang terdiri dari tugas kinerja, kisi-ksi instrumen, petunjuk penggunaan, lembar observasi peserta didik, rubrik penilaian, pedoman konversi penilaian sesuai kurikulum 2013, dan rekapitulasi nilai akhir. Perangkat performance assessment sudah layak secara substansi, konstruksi, dan kebahasaan; (2) Perangkat performance assessment ini telah direspon positif oleh guru pengguna karena memiliki kesesuaian, kemudahan dan kemanfaatan; (3) Penggunaan perangkat penilaian ini dalam pembelajaran direspon positif oleh peserta didik sehingga memberikan hasil belajar yang baik; (4) Perangkat performance assessment telah disusun berdasarkan $\mathrm{KI}$ dan $\mathrm{KD}$ dan penyusunan kriteria mengacu pada literatur sehingga tidak menimbulkan persepsi diantara pennguna serta subyektivitas dalam penilaian peserta didik dapat terhindarkan.

\section{DAFTAR PUSTAKA}

Arikunto, S. 2013. Prosedur Penelitian. Suatu Pendekatan Praktik, Jakarta: PT. Rineka Cipta.

Azwar, S. 2009. Reliabilitas dan Validitas (Edisi ke 3). Yogyakarta: Pustaka Pelajar Offset.

Badrul, M. Mutamman dan Teguh, M. Budiarto 2013. Pemetaan Perkembangan Kognitif Siswa SMA Menggunakan Tes Operasi Logis (TOL) Piaget Ditijau Perbedaan Jenis Kelamin. Jurnal On Line Vol. 2. No. 2. UNESA.

Depdikbud. 2013. Peraturan Menteri Pendidikan Dan Kebudayaan Nomor 66 Tahun 2013 tentang Standar Penilaian. Jakarta: Depdikbud.

Hutabarat, O.R. 2015. Model-model Penilaian Berbasis Kompetensi PAK. Diakses: 20 Desember 2015. Tersedia:

:http://www.kajianpustaka.com/2012/ 11/penilaian-kinerja-performanceassessment.html.

Isyanti, Puji. 2015. Penilaian Unjuk Kerja. Diakses: 20 Desember 2015. Tersedia:

:http://www.kajianpustaka.com/2012/ 11/penilaian-kinerja-performanceassessment.html.

Khadijeh, B. \& Amir, R. 2015. Importance of Teachers' Assessment Literacy. International Journal of English Language Education. Vol. 3, No. 1. doi:10.5296/ijele.v3i1.6887URL:http:

//dx.doi.org/10.5296/ijele.v3i1.6887

Marmara. 2008. Performance Based Assessments: Theory and Practise. Journal of Turkish Science Education, Vol. 5, Issue 1.

Oberg, C. 2012. Guiding Classroom Instruction Through Performance Assessment. Journal of Case Studies in Accreditation and Assessment. Vol. 1. No.1. 
Omidi, M. Sridhar. Y.N. Azizmalayeri, K. 2012. Effektiveness of Assessment Patterns in Chemistry Learning. Journal of Life Science. Vol. 9 No. 3.

Popham, W.J. 2011. Classroom Assessment: What Teachers Need to Know. (6th ed.). Boston, MA: Pearson Education, Inc.

Ridwan, 2011. Skala Pengukuran dalam Penelitian. Bandung : CV. Alfabeta
Yuen, C.F \& Kaur, G.S. 2010. Authentic Assessment and Pedagogical Strategies in Higher Education. Journal of Social Science. Vol. 6. No. 2

Wren. G. Douglas. 2009. Performance Assessment: A Key Component of Research, Evaluation, and Assessment. Report from the Department of Research, Evaluation, and Assessment. No. 2. R. 